\title{
Stories of Menacing Globalization: A Review of Two Books
}

\author{
Kurt Burch
}

Susan Strange (1996) The Retreat of the State: The Diffusion of Power in the World Economy. New York, NY: Cambridge University Press. 218 pages. $\$ 16.95$ paperback.

Martin J. Beck Matustik (1998) Specters of Liberation: Great Refusals in the New World Order. Albany, NY: State University of New York Press. 360 pages. $\$ 23.95$ paperback.

In 1996, Philip Cerny wrote in the International Journal that globalization literature is a set of contested stories that frame the categories and concepts informing public debate. Retreat and Specters tell such stories to shape perceptions of globalization as a threat demanding vigorous scholarly attention and creative political responses. Both books depict globalization as a frightening menace heralding social tumult; dislocation; "a yawning hole of non-authority" (Strange, p. 14); and a terrifying legacy of "economic immiseration, political oppression, cultural marginalization, and racial and ethnic cleansing" (Matustik, p. x). Strange outlines potential threats, leaving readers to conjure responses. Matustik seeks to open the conceptual space necessary to craft alternative conditions, leaving readers to specify the threats and imagine how to achieve alternatives. Neither author explains or analyzes globalization. Strange disdains globalization as no more than empty jargon, and describes it as an economic and technological phenomenon with political consequences. Matustik considers it to be social with political and cultural consequences.

Both authors address prevailing stories of globalization as much as global conditions. Each exhorts readers to confront globalization by exploring the gritty reality and actual conditions confronting individuals, rather than by accepting prevailing stories. Thus, each confirms Cerny's 
claim (1996:260) that globalization is more significant as a contested discourse than as an analytical literature or global condition. In this light, one does well to read Strange and Matustik as storytellers and to ask if their interpretive tales reflect one's experiences and impressions of global life. Unsurprisingly, both authors tell only partial tales, but each poses worthy questions.

Retreat builds upon Strange's States and Markets (1988; 1994 Pinter) and Rival States, Rival Firms (1991 Cambridge). For Strange, globalization fractures and disperses authority, and thereby reconfigures the global system and heightens anxieties about future conditions. The measure of such anxiety is that transnational agents now wield authority that was once the province of states. The primary catalyst for these changes is technological innovation, which hastens the speed and scope of global finance and enmeshes national economies in a global market. The transition (transformation?) from eroding state authority to expanding transnational sources yields three unsettling conditions: power diffuses throughout the global system upwardly from weak states to powerful states, and horizontally from states to markets and nonstate actors; conflicting sources of authority arise; and significant responsibilities go unmet (Strange, p. 189). Wrought by this turmoil are financial instability; locally intractable conflicts that forswear the rule of law (e.g., Africa, the former Soviet Union, Algeria, the Balkans); diminished public accountability of the state; insufficient democracy; and fragmenting allegiances, loyalties, and identities that initiate an "absence of absolutes."

Strange tells this story of globalization's debilitating, fragmenting consequences by telling thin, unpersuasive stories of six transnational sources of authority: telecommunications conglomerates, organized criminals, insurance underwriters, the Big Six accounting firms, cartels, and international organizations. By her admission, these chapters amount to "scrappy descriptions" (p. xvi). Though insightfully provocative, they are not analytical. In these pages we read Strange-the-former-journalist. However, both her purpose and her means remain clear: in dark and foreboding terms she intones that "poetry and drama are full of stories in which the unraveling of a chain of causes and effects is totally unforeseen and often ... profoundly tragic" (p. 29). She concludes ominously that "the stories told here suggest that ... complacence may easily be overdone" (p. 197).

Strange warns readers to be wary of the diffusion of authority, an event precipitated by globalization. She characterizes globalization via two fundamental premises. First, the rapid pace of technological innovation fuels competition for global market shares. This competition has eclipsed competition for territory and resources as the driving force of 
global political economy relations. However, the escalating costs of researching, developing, producing, and applying technological innovations burdens firms, reshapes markets, and underscores the place of finance in the global economy. As a result, huge transnational corporations, banks, accounting firms, insurers, and the like now wield considerable political and economic influence. For Strange, such influence generates power and authority. The second premise records this shift: the diffusion of national authority causes conditions of "ungovernance," whether from neglect or inability (p. 14). In this story, economic globalization yields political tumult and tragedy.

Strange despairs over lost stability and evaporating accountability. As the power of impersonal global markets eclipses national governments, supreme political authority no longer resides in states, where it "is supposed to belong" (p. 4; italics added). Moreover, many states are increasingly "deficient" in their responsibilities. This surprisingly conservative claim goes unexplored. Yet here Strange signals another story running as a subtext throughout her tale: globalization threatens to undermine the state system, which she assumes is the proper arrangement of social and political life. Globalization delivers not opportunities and adventures, but casts a shadow of anxiety, decay, and catastrophe.

To confront such foreboding circumstances, Strange leads a righteous march against the state-centric constraints of the discipline of international relations (IR) as she exhorts readers to the "imperative of multidisciplinarity" (p. xv). Analysts need to climb out of the analytic confines of the state as a disciplinary premise in order to make sense of the state, authority, and politics as social subjects. By such calls, Strange advocates reconceiving the state and its place in the global system, reconceptualizing the fields of political science (PS) and IR, and relocating them within the social sciences.

Yet such claims and calls have circulated outside of PS for generations, and in IR since at least Richard Cooper's The Economics of Interdependence in 1968. Strange alludes to these challenges, but neither contributes nor critiques. Indeed, she oversimplifies. For example, although state-centric neorealism marks the mainstream literature in IR, it must contend with several alternative approaches. Much significant work in IR and IPE considers the interactions of states and transnational actors, shunning either/or accounts. Several constructivist analysts also avoid state-centric frameworks. Similarly, Immanuel Wallerstein challenged narrow disciplinary frameworks over 25 years ago, and many IPE theorists in the last generation have sought to overcome the politics/economics and national/international distinctions. 
Beyond oversimplification, several other matters also may distract readers. First, Strange does not make her subject clear. Though her previously published work bears many of Retreat's analytic and conceptual burdens, its shifting foci blur the central issues and their interactions. Is her foremost concern stability? Order? Tradition? Is she addressing authority? Power? Politics? The state? Sovereignty? Does she regard sovereignty as a condition, a practice, or a legal term with functional and judicial distinctions? Is sovereignty eroding? Diffusing? Not changing at all? Or are shifting global conditions altering their relationship to sovereignty? How are we to untie the conceptual knot comprising sovereignty, authority, politics, law, rights, power, political control, the state, market authority, and corporate political authority, all of which are invoked on page 45 ? Since much is uncertain, readers may not know which leads to follow, which strand of Strange's story to track. Strange derides the voguish concept of globalization as "a term which can refer to anything from the Internet to a hamburger" (p. xiii). One might say the same about her conception of authority and related terms.

Second, Strange offers no theory of change. Her descriptions capture contemporary conditions of corporate growth and technological wizardry, but conveys no clear sense of how and why such changes are occurring. Is technological innovation the sole catalyst? Does she mean the Information Revolution, or is she asserting some fundamental change in the pace, scope, and character of innovation? Patenting data and similar measures, for example, do not corroborate the latter claim. What is technological innovation affecting? Authority or power? State or sovereignty? Material conditions in the global system or perceptions of that system? Are the global system and sovereignty changing independently of technological change? Are these changes of degree or kind? What thresholds are breached?

Since such matters are unclear, Retreat reads more as a story than as a careful analysis. Strange asserts that transformation is occurring and inventories diverse changes, but does not explain fully how or why the changes occur. Her story assumes that assertions suffice. To answer the many questions that arise, we need from Strange a crisper plot and a third act. We must engage other globalization stories.

Strange's enduring contribution is that her brisk prose, demands for simplicity and commonsense, and novel frameworks make global issues readily digestible. Others may polish and groom the details; she tells an exciting tale that poses many challenging questions worthy of attention. Notably, she asks if the institutions arising from globalization can foster individual autonomy, enhance democratic practice, and promote public accountability. Her skepticism leads her to advocate institutional balances 
of power and to call for ethical choices. Relatedly, she also asks what kinds of novel political theory might be required to help illuminate changing conditions and light the way to desirable outcomes? Matustik explores these questions in Specters to put an optimistic spin on the familiar tale of global menace.

Matustik condemns the haunting menace of a culturally homogenizing globalization that immiserates billions of people and promises politically sterile and enfeebled forms of democracy. He believes that his dissent bonds him to the great critical theorists and to the marginalized people who protest social wrongs and cultural uniformity. Upon a foundation of "multicultural democracy," he seeks to create a theoretical and conceptual space for conceiving alternative political relations. Such democracy, he argues, is one possible outcome of the multidimensional forms of identity fostered by the New World Order engendered by globalization. Rather than see fragmented identities and fractured loyalties, Matustik conceives of "postnational identities" that overcome the narrowly partisan constructions of nation, race, gender, religion, and such.

Matustik also tells a story about stories. He rhetorically asks which story about globalization shall we tell (p. 201)? Which story will endure to dominate discourse, discussion, and popular perceptions? "Which are the specters of liberation, which are the specters of living hell" (p. 251)? The first story, trumpteted in the First World, hails the apparent victory of liberal democracy and free marketeering since 1989. A second story recounts the increasing social, political, economic, and cultural exploitation caused by flaccid democratic arrangements and the culturally homogenizing effects of integrated global markets. This is a story from the margins and from much of the impoverished Third World and Fourth World. A third tale outlines the prospects for new political and economic forms that heighten multicultural democracy in light of the overlapping and invented identities arising from the complexity and heterogeneity embedded in global relations (see also Cerny, 1996:626). This tale is obscured by the naivete and gloom, respectively, of the other stories.

Matustik preaches this third gospel. He advocates social alternatives by inserting thumbnail references to examples of exploitation and resistance, such as the Chiapas Rebellion and the Velvet Revolution in the former Czechoslovakia that brought Vaclev Havel to power. Oddly, Matustik does not consider altering the political-economic conditions of globalization. Rather, like Strange, globalization looms like a menacing monster, the threat being all the more palpable because of the frightening folktales that endure. Matustik hopes that enhanced democratic practices will make living with(in) the beast more tolerable. His contribution is to rethink 
contemporary political theory in order to address challenges posed by globalization's conditions and myths.

Matustik does not conceive of globalization in terms of authority. The source of authoritative decisions matters little, since exploitation endures. (In contrast, Strange is keenly interested in the procedures and institutional sites of decisionmaking, not necessarily in distributive outcomes.) Globalization poses a formidable threat because of the striking oppression it causes. This story is especially menacing, since Matustik regards contemporary conditions as the most recent manifestation of a 500-year legacy of exploitation (p. x). Yet tales of such misery are conveniently eclipsed by the popular tale of liberal-democratic victories. Matustik refuses to abide both the tale of unremitting immiseration and the story of liberal resurgence. He seeks solace in the company of scholarly dissenters in social theory and activist dissenters in global affairs who shout "great refusals"- that is, they dissent from the established global and national orders and advocate greater democratic freedom.

Globalization and dissent offer opportunities that were not conceived of by Strange. Although globalization threatens cultural homogenization and market integration, it also sparks dramatic reconfigurations of identity and interests. Witness the clashing identities in genocidal Bosnia and the unlikely alliances in Northern Ireland. From these postnational identities, Matustik seeks to fashion a rich, fluid, and multidimensional form of democracy (see also Matustik, 1993, Postnational Identities). He hopes to secure leverage against the political and cultural structures that foster a blanched, oppressive social life by rethinking notions of identity and reinvigorating critical social theory. The recognition that identities are no longer overwhelmingly one-dimensional and the insights of redirected social theory become tools for opening personal and collective liberation. Thus, Matustik's optimism lies in a hope and a politically creative impulse.

To make his case for multicultural forms of democracy, he idiosyncratically weaves select political theorists and philosophers: Marcuse's "great refusal," Kierkegaard's radical individualism, Taylor's communitarianism, Habermas's communicative ethics, the attention leveled by critical theorists upon the institutions of power and authority yielding domination and exploitation, Foucault's "strategies of knowledge," and more. The effort is at times strikingly creative, at other times sclerotically dense and numbingly arcane. Thus arise the significant problems that mar the presentation.

Resisting his own demand to investigate "lived lives," Matustik embarks on a demanding philosophical and textual exegesis that taxes the patience and understanding of even attentive readers. Further, when he 
does mention contemporary events or conditions, his tone is flippant and his coverage is cursory. Such references serve as signifiers of some deeper or larger unspoken point, and they only feebly buttress his analyses. I craved a real-world example that ably illustrated an accompanying point. Ironically, Matustik devotes his attention to creating conceptual space for conceiving alternative forms of democracy, but does not consider what a multicultural form of democracy would entail. What would such practices involve? If the Chiapas Rebellion is a symbolic victory worthy of his praise, then are Chechnia, Kosovo, and Bosnia symbols of equally dismal failure? Is the ouster of Zaire's despotic Mobutu by Laurent Kabila's forces in 1997 a virtuous example? Do the challenges to Kabila in 1998 repudiate the example? What of the partisan politics in Algeria, Northern Ireland, and the Balkans, where brutal power is exercised to forge virtually one-dimensional identities and eradicate others? Similarly, the repressive governments of Myanmar (Burma), Nigeria, and China crush dissent and eliminate such undesirable "identities," as gays, feminists, and democratic activists.

Do localized politics make better examples? Do protests by Turkish villagers against the construction of nuclear power plants illustrate multicultural democracy? Does the occupation of land in Brazil orchestrated by Sem Terra, the Brazilian landless movement, constitute multicultural politics? Since 1990 , over 150,000 families in this sizable movement have occupied areas of Brazil larger than Nebraska. What of the Landless Workers Movement of Brazil, which in the summer of 1998 moved systematically to loot groceries, food warehouses, and food trucks in response to a devastating drought and government inaction? Is this simple desperation? Bottom-up politics? Or praiseworthy political dissent? Matustik provocatively declares that "a communally determined takeover of sustainable rural or urban territory could not be viewed as a riot or looting" (p. 163). While perhaps normatively defensible, how do such acts exemplify or foster multicultural democracy? Why are squatting and looting not examples of forcible resource distribution? These are not simple semantic distinctions. Since one is unclear about what counts as an example of multicultural reaction to globalization, one is equally unclear about what to make of potential examples.

A second difficulty is Matustik's inattention to the informal, mechanical politics of coalition-building, agenda-setting, candidate platforms, and the like that are important for realizing his ambitions. Perhaps such matters are too strictly liberal democratic, but they need not signal acquiescence to tepid liberalism. Yet other than arm's-length or obscure references, Matustik ignores grassroots movements and widespread protest, except to dive into the deep nuances of Czech politics. This is too little and 
too much. Both Strange and Matustik are anxious about how to fulfill democratic practice and accountability. While Strange remains uncertain and craves new ideas for coping with fragmenting identities, Matustik revels in the same circumstances but only sketches possible alternatives.

Such abstraction may arise from Matustik's deeply informed theoretical approach. Though his goal is to create a theoretical space for conceiving a multicultural democracy, one nonetheless wishes for a touchstone example. From Matustik's perspective, why should we care about arcane debates involving Habermas, Taylor, and Derrida more than about creative politics from the social margins? I craved more of Matustik's thoughtful interpretations of the Chiapas Rebellion, for example, and less about whether "existential-social performatives ... provide a basis for the substantive and at the same time nonessentializing, concretely-perspectival critical theory" (p. 155).

Though it is a mistake to read Matustik as a revolutionary theorist, it is equally mistaken to read him as a revolutionary activist. We must read him as an insightful, concerned theorist who struggles to relieve material misery and engage concrete conditions. How does the glimmer of hope he strives to discern (and create) become a spark? What exactly are the incendiary qualities of those glimmers? How does a spark of activism become an enduring flame that fires political passions and lights political movements? Such matters Matustik cannot answer, save to invoke his experiences as a Czech expatriate. Will hope sustain us?

As hope is a matter of disposition and ideas, Matustik considers globalization's political and cultural features, rather than the material matters of economy and technology that preoccupy Strange. Globalization is a menace requiring no explanation, because it (allegedly) self-evidently homogenizes prevailing ideas to produce a one-dimensional social life that cruelly transforms political hope into market improbabilities. $\mathrm{He}$ offers no theory for why the oppression of narrow ideas and sterile democracy arises from globalization or from Western stories about global relations. Indeed, he offers no theory of technological change, capitalism, changing economic markets, states, the global system, cultural imperialism, or ideology. Last, he provides no explanation for the tension between homogenizing cultural forces and fragmenting political relations. That is, by sleight of hand his story of globalization's menace reconciles clashing interpretations of globalization. No mention of paradox, simultaneity, or dialectic. He delivers breezy bromides instead: "inventing emancipated life, leaping out of the rhetoric of one-dimensionality (out of the hegemonizing NWO), demands transformations within the established society ... [to upset] the fake carnival of the established order" (p. 195, internal quotations and italics deleted). 
Both Strange and Matustik conclude with their premises: globalization is a foreboding threat. Neither crafts a coherent response to the perceived menace, so both wring their hands. Strange despairs, suggesting that the world should pay attention and ponder the difficult questions of accountability. She offers no leads. Matustik takes up Strange's challenge, but the route he charts winds through the thin air of abstract theory. Few may want to follow-or be able to follow-him. Thus, one may chose among competing stories and pick one's own menace and remedy, as it were. Such is the way of discourses and the entwined stories characterizing globalization. We confront conditions and perceptions.

The virtue of such books and their partial stories is that they highlight the wider frameworks necessary to comprehend the deeper complexities of global life. For that we can be thankful for contested stories. Strange and Matustik also illustrate that such a need underscores the opportunity to reconstruct how we conceive of social science, social life, and their purposes. For that we can thank the menacing stories of globalization. Last, both authors turn us to ethical, responsible choices. Strange gravely declares that amid such tumult, "our individual consciences are our only guide" (p. 199). Matustik hails a "new social consciousness." Thus, he also proclaims novel individual consciences directed toward conscientious objection and relief of the oppressed. "Our chances and hope in the present age rise and fall with their liberation" (p. 266). For that we can be hopeful. 